\title{
TOLD NERVOUS SHOCK: HAS THE PENDULUM SWUNG IN FAVOUR OF RECOVERY BY TELEVISION VIEWERS?
}

\author{
RAMANAN RAJENDRAN*
}

['Nervous shock' was recognised as a recoverable form of injury in the early 1900s. Only recently however this form of injury has received extended coverage in the High Court of Australia and the legislature. Unfortunately, there are few clear guidelines, especially from the High Court judgments. This article discusses the implication of the recent decisions of Tame and Annetts and Gifford, as well as the history of 'nervous shock' and statutory developments. It seeks to clarify the approach of the High Court and the legislature in the area of nervous shock, especially as it relates to recovery for 'nervous shock' by viewers of distressing events on television.]

\section{INTRODUCTION}

In a litigious society, it is all too easy to regard as frivolous claims for psychiatric illness, especially when there is no accompanying physical injury. After all, it is generally invisible to the untrained eye and seeing is believing. Psychiatric injury (often referred to as 'nervous shock') is neither trivial nor frivolous and is now generally recognised by both the legal and medical professions as worthy of recovery. As Gummow and Kirby JJ noted in Tame and New South Wales and Annetts $v$ 
Australian Stations Pty Ltd, ${ }^{1}$ there have been advances in the capacity of medicine to objectively distinguish the genuine from the spurious.

This topic is set to receive attention by the NSW Supreme Court, in Klein $v$ New South Wales, ${ }^{2}$ following Master Harrison's decision not to rule in favour of an application by the Defendant to strike out the Plaintiffs' Statement of Claim. The Plaintiffs were family members (i.e. parents, siblings, wife and sister-in-law) of Paul Klein, who was shot dead by the NSW police following a domestic disturbance.

Paragraph 22 of the Statement of Claim pleaded that on the morning of 27 May 1998 and on various occasions thereafter, each of the Plaintiffs saw on television and in the print media graphic images depicting the events leading up to and surrounding the death of Paul Klein. The Plaintiffs pleaded that the media representatives were non-essential personnel present at the scene of the shooting of the deceased that exacerbated the danger to members of the public. The alleged breach of duty was a failure to establish a perimeter around the scene to exclude all other than essential personnel, restrict access to the scene and to clear the area surrounding the perimeter.

The Master allowed the matter to proceed to trial, and in refusing the dismissal application of the Defendant, he said:

...the Court should be particularly astute not to risk stifling that development of the law by summarily throwing out of court actions in respect of which there is a reasonable possibility that it will be found, in the development of the law, still embryonic, that a cause of action does lie... One cannot predict, with firm assurance, what the future holds as the final formulation of the new development. ${ }^{3}$

This paper will explore the plight of people who suffer 'nervous shock' from viewing distressing events on television. In cases such as these, loosely referred to as 'communicated or told nervous shock', recovery is much more restrictive than 'psychiatric injury' accompanied by physical injury. ${ }^{4}$ In the words of Associate Professor Danuta Mendelson, it is imperative that the law determines whether 'communicated nervous shock' should be recoverable, especially given technological advances in communication. ${ }^{5}$

\footnotetext{
"Articled Clerk, Abbott Stillman \& Wilson. I would like to thank Associate Professor Danuta Mendelson, Deakin University, and Leanne Misquitta for reading my drafts and their constructive comments.

1 (2002) 211 CLR 317, 378 ('Annetts').

${ }^{2}$ [2004] NSWSC 837 ('Klein')

${ }^{3}$ Ibid 10.

${ }^{4}$ Law Reform Committee, Commonwealth Parliament, Review of the Law of Negligence Final Report (2002) <http//revofneg.treasury.gov.au>.

${ }_{5}^{5}$ Danuta Mendelson, The Interfaces of Medicine and Law - The History of the Liability for Negligently Caused Psychiatric Injury (Nervous Shock) (1998) 218.
} 
Whilst the Australian High Court has addressed the issue of 'communicated nervous shock', as recently as June $2003,{ }^{6}$ it has not had the opportunity to make a definitive finding on recovery by television viewers. It is the author's contention that despite authority to the contrary, especially in the UK, claimants in limited cases are likely to recover. This proposition will be explored below.

As a final introductory point, it is important to note that this paper will not explore medical evidence even though there is substantial medical evidence supporting recovery by claimants who are not present at the scene of the incident or its immediate aftermath. ${ }^{7}$ Similarly, this paper will only consider claims against the original tortfeasor, rather than those who relay the news (such as television stations), ${ }^{8}$ and recovery for pure mental harm rather than mental harm consequential upon physical injury. The author also accepts the proposition that recovery will only be allowed for recognisable psychiatric injury rather than sorrow or mere grief. ${ }^{9}$ Common law developments are discussed at length despite recent legislative enactment because the legislature, to a large extent, has taken its cue from the common law.

Before discussing the history, it is important to briefly discuss the policy implications.

\section{PoLICY}

The policy reasons for allowing or disallowing recovery will only be discussed briefly because extensive material has already been published on policy matters in negligence and this paper endeavours to discuss the law rather than policy matters. ${ }^{10}$ The Ipp Report addressed the reasons why the law has made it harder to recover for negligently occasioned psychiatric injury than physical injury. ${ }^{11}$ It felt the most important ones were - (i) the difficulty of proving the existence and extent of mental harm; (ii) it would be harder to foresee the number of people who may suffer mental harm as opposed to physical harm; and (iii) because resources are limited, it is more important to compensate people for physical harm than for pure mental harm.

\footnotetext{
${ }^{6}$ Gifford v Strang Patrick Stevedoring Pty Ltd (2003) 214 CLR 269 ('Gifford').

${ }^{7}$ Mendelson, above n 5, 230; Harvey Teff, 'Liability for Negligently Inflicted Nervous Shock' (1983) 99 Law Quarterly Review 100, 107; Chris Tennant, 'Liability for Psychiatric Injury: an Evidence-Based Appraisal' (2002) 76(1) Australian Law Journal 73.

${ }^{8}$ The author was dissuaded in exploring liability of television stations by conclusion of some respected writers that such liability is unlikely. In particular see Des Butler, 'Mass Media Liability for Nervous Shock: A Novel Test for Proximity' (1995) 3 Torts Law Journal 75.

${ }^{9}$ Des Butler, 'Identifying the Compensable Damage in "Nervous Shock" Cases' (1997) 5 Torts Law Journal 67.

${ }^{10}$ See generally, Des Butler, 'An Assessment of Competing Policy Considerations in Cases of Psychiatric Injury Resulting from Negligence' (2002) 10 Torts Law Journal 13.

${ }^{11}$ Law Reform Committee, above n 4, 9.4
} 
One more relevant policy consideration, which is relevant to our discussion but not covered in the Ipp Report, is the 'freedom of press'. Dealing with this first, it has been put forward that holding the original tortfeasor liable will be a restriction on the freedom of the press. The validity of this view is questionable for two reasons -

(i) the claim is not being made against the television stations rather it is made against the original tortfeasor (in Klein the police officers and the State); and

(ii) the issue is whether the original tortfeasor could have reasonably foreseen the 'not insignificant' risk that persons of a specific class would suffer psychiatric injury from viewing events, which were caused by its negligence, unfold on live television. It is not whether the television stations were negligent in broadcasting the 'event'.

Next, in this day and age it is inappropriate to rely on 'floodgate' arguments to prevent recovery. First, it is now generally accepted both medically and legally that mental harm is equal to, and at times more detrimental than, physical harm. ${ }^{12}$ Second, the floodgates are unlikely to open given that there are several limitations still applicable. Not only does a claimant have to prove the existence of a psychiatric injury through expert evidence; they also must prove foreseeability of mental harm. Third, given the technological advancements and medical knowledge, it is foreseeable that people will suffer mental harm. Fourth, mental harm is equal to physical harm and it is unlikely that the courts will limit recovery if 10,000 people are physically injured through the negligence of the defendant. Finally, as has been recognised by the Ipp Report, the drawing of arbitrary lines is not good policy, as it will result in inconsistent and unfair results, as it did in Alcock. ${ }^{13}$ Consequently, the 'floodgates' arguments are inappropriate and prevent recovery even in genuine cases.

\section{A Short History Lesson in Nervous Shock}

One of the first cases to consider recovery for 'nervous shock' was Victorian Railways Commissioner $v$ Coultas. ${ }^{14}$ A gatekeeper on a level crossing had negligently left the gate open, allowing $\mathrm{Mr}$ and Mrs Coultas to cross when the train was approaching. They narrowly avoided the train, but Mrs Coultas suffered psychiatric injury as a result of the near miss. Whilst initially successful, on appeal, the Privy Council held that damages arising from mere sudden horror, unaccompanied by any

\footnotetext{
${ }^{12}$ Butler, above n 10

${ }^{13}$ Law Reform Committee, above n 4, 141

${ }^{14}$ (1888) 13 App. Cas. 222.
} 
physical injury, but occasioning psychiatric illness, could not be considered a consequence, which would follow from a negligent gatekeeper. ${ }^{15}$

The defendant in Coultas argued that there had to be some contemporaneous physical impact before recovery should be allowed for psychiatric injury. Although the Privy Council did not require physical impact, various subsequent authorities cited 'physical impact' as the explanation for its refusal to allow recovery.

In Dulieu $v$ White ${ }^{16}$ Justice Kennedy held that a person could claim for psychiatric injury only if they were themselves within the range of potential physical harm. ${ }^{17}$ Kennedy $\mathbf{J}$ stated that recovery for nervous shock will only be allowed if the injury arose "from a reasonable fear of immediate personal injury to oneself." 18 This limitation was later relaxed by the Court of Appeal in Hambrook v Stokes, ${ }^{19}$ where a mother was allowed recovery after suffering psychiatric illness from anticipated injury to her children, even though she did not observe her children being harmed. Mrs Hambrook eventually discovered that her daughter Mabel was seriously injured. In allowing recovery however the court excluded recovery where the nervous shock was suffered following third party communication of the incident. Lord Oliver in the 1992 decision of Alcock, espoused the proposition that claimants suffering psychiatric illness may recover if they viewed the incident with their "own visual perception" rather than through third party communication. ${ }^{20}$ This requirement of "own visual perception" is the primary threat to recovery for "nervous shock' by claimants who view distressing events on television broadcasts because viewing through this medium is unlikely to be equivalent to 'own visual perception'.

Despite the courts' refusal to award recovery where a claimant was not in physical danger $^{21}$ or where they did not actually see a loved one in physical (or perceived) danger, the case law makes it clear that the law is on the move. This was illustrated in the case of Mount Isa Mines v Pusey ${ }^{22}$ where the High Court allowed an employee to recover for psychiatric illness which arose from his attempts to assist two fellow employees who were 'just burnt up', through the negligence of the employer. Recovery was allowed despite the plaintiff being unacquainted with the burn victims, who later died, and he himself not being in any physical danger. It appeared from most of the judgments that the relationship between the tortfeasor and the plaintiff was relevant to the issue of liability. ${ }^{23}$ The court did not place special restrictions on recovery for nervous shock, and this was clear in the judgments of

\footnotetext{
${ }^{15}$ Ibid 225

${ }^{16}$ [1901] 2 KB 669

${ }^{17}$ Dulieu v White [1901] 2 KB 669, 675.

${ }^{18}$ Ibid.

${ }^{19}$ [1925] 1 KB 141.

${ }^{20}$ Alcock v Chief Constable of South Yorkshire Police [1992] 1 AC 310, 412.

${ }^{21}$ Bourhill v Young (1943) AC 92

${ }^{22}$ (1970) 125 CLR 383.

${ }^{23}$ Ibid 389 (Barwick CJ), 391 (McTiernan J), 392 (Menzies J), 399 (Windeyer J) and 411 (Walsh J).
} 
Justices Windeyer ${ }^{24}$ and Walsh. ${ }^{25}$ The law was therefore developing in incremental steps to meet new situations of psychiatric injury, at least until the decision of the House of Lords in McLoughlin v O'Brian. ${ }^{26}$

\section{LORD WILBERFORCE AND THE THREE 'Control Mechanisms'}

Lord Hoffman in White v Chief Constable of South Yorkshire Police ${ }^{27}$ summarised McLoughlin v O'Brian ${ }^{28}$ and its relevance to 'nervous shock' succinctly. He said that the law "came within a hair's breadth" of establishing foreseeability as the sole criterion for liability for psychiatric injury. It was 'one of those cases in which one feels that a slight change to the composition of the Appellate Committee would have set the law on a different course. ${ }^{29}$ He was referring to the fact that out of the five Law Lords, two were against establishing additional limits (Lords Bridge and Scarman) and two were for establishing greater controls for recovery (Lords Wilberforce and Edmund-Davies), whilst Lord Russell failed to provide a clear opinion on this issue. Lord Wilberforce's judgment was adapted in England and by the Australian High Court, although only to a limited extent. ${ }^{30}$ This led to an era of blind faith in His Lordship's pronouncement, even though it was not in the majority, as far as his reasoning was concerned, ${ }^{31}$ producing unfair and inconsistent results.

It is necessary to examine the McLoughlin case in some depth to obtain an understanding of why television viewers may be barred from recovery for nervous shock. The litigation arose from horrific circumstances. The defendant's negligent driving had caused a road accident in which the plaintiff's daughter was killed and her husband and other children had been badly injured. The plaintiff was not at the scene and did not hear of the accident until two hours later. She did not see its consequences until she went to the hospital. She was allowed to recover for the psychiatric injury she suffered, as it was held that she had arrived at the 'aftermath', which included the hospital where the victims were still effectively in the state they were in after the accident. Despite the lack of uniformity in the reasoning, the entire House of Lords allowed the appeal in her favour. We will begin with the judgment that had the most impact upon recovery for 'nervous shock', that of Lord Wilberforce.

\footnotetext{
${ }^{24}$ Ibid 401 .

${ }^{25}$ Ibid 392

${ }^{26}$ Oliver Segal and J M Williams, 'Psychiatric Injury, Policy and the House of Lords' (1999) Journal of Personal Injuries Litigation 102, 103.

${ }^{27}$ [1998] 3 WLR 1509, 1548-9.

${ }^{28}$ [1983] 1 AC 410.

${ }^{29}$ Ibid.

${ }^{30}$ Jaensch v Coffey (1984) 155 CLR 549 ('Jaensch').

${ }^{31}$ United Kingdom, Liability for Psychiatric Injury, Law Committee Report No 249 (1998).
} 
Lord Wilberforce from the outset ${ }^{32}$ sought to limit recovery in psychiatric injury cases - '...the boundaries of a man's responsibility for acts of negligence have to be fixed as a matter of policy.' He added - '...foreseeability must be accompanied and limited by the law's judgment as to persons who ought, according to its standards of value or justice, to have been in contemplation.' He was so heavily influenced by policy against a wider extension; ${ }^{33}$ it is little wonder that he felt it necessary to impose the three limits to be considered.

His Lordship pronounced the limits on psychiatric injury cases, ${ }^{34}$ which until recently would have barred recovery by television viewers. The Californian Supreme Court had formulated three similar factors that were to be assessed as part of reasonable foreseeability in Dillon v Legg. ${ }^{35}$ First, Lord Wilberforce placed a limit on the class of persons who may claim. Whilst he said that '...the closer the tie (not merely in relationship but in care) the greater the claim for consideration', he recognised only the closest of family ties (that of parent and child and husband and wife).

Second, he required proximity to the accident "in both time and space." This he defined as direct and immediate sight or hearing of the incident or the aftermath (i.e. those who come upon the scene very soon). This would most likely rule out even claimants with close tie and affection unless they came upon the immediate aftermath. This may mean, for example, that one sibling who is in a close relationship to the victim is likely to recover if he/she was at the scene, but another sibling who is in a similar close relationship may be refused recovery merely because he/she was not at the scene or its immediate aftermath. This approach defies logic.

The final 'control mechanism' was that shock caused by way of communication was not recoverable. This would exclude nervous shock caused by communication of a distressing event by a third party, which may or may not include a television broadcast. On a positive note however his Lordship refused to rule out ${ }^{36}$ the possibility that a simultaneous television broadcast may be equivalent to sight or hearing of the event or its immediate aftermath.

Despite the three limitations on recovery, it is unlikely that even Lord Wilberforce meant for them to be applied without flexibility:

It is necessary to consider three elements inherent in any claim. I believe that these indications [i.e. the three factors], imperfectly sketched, and certainly to be applied with common sense to individual situations in their entirety [represent existing law]... ${ }^{37}$

\footnotetext{
${ }^{32}$ McLoughlin v O'Brian [1983] 1 AC 410, 420

${ }^{33}$ Ibid 421 .

${ }^{34}$ Ibid 422.

35 (1968) 441 P 2d 912.

${ }^{36}$ McLoughlin v O'Brian (1983) 1 AC 410, 423.

${ }^{37}$ Ibid.
} 
This warning therefore places serious doubts over the reliance on His Lordship's judgment as the reason for restricting recovery. His Lordship's repeated warnings were not heeded and these rules appear to have been applied stringently, at least until the recent cases of Annetts and Gifford.

Similarly, Lord Edmund-Davies refused to allow foreseeability to be the sole determinant of negligence actions but he did not provide details of other tests that should be applied. Whilst his Lordship demanded more controls, he was uneasy with inflexible rules and was rather persuaded by public policy. He did not however appear to have explicitly accepted Lord Wilberforce's three control mechanisms.

In contrast to the stance of Lords Wilberforce and Edmund-Davies, Lord Scarman was not convinced that strict rules were required. ${ }^{38}$ He noted that 'space, time, distance, the nature of the injuries sustained, and the relationship of the plaintiff to the immediate victim of the accident, are factors to be weighed, but not legal limitations, when the test of reasonable foreseeability is to be applied. ${ }^{39}$ He wished for principles to be guiding lights but not tyrannical masters in their own right. Yet he predicted social and financial problems if "...damages for "nervous shock" should be made available to persons other than parents and children who without seeing or hearing the accident, or being present in the immediate aftermath, suffer shock in consequence of it.' Lord Wilberforce's tests therefore would have a bearing on recovery, although they would not necessarily preclude a claim. ${ }^{40}$ Whilst recovery is more probable for the television viewers, the absence of the aforementioned factors would create doubt over a successful claim, especially in the case of those who did not perceive the distressing event and those who do not fall within the close family criterion.

Finally, Lord Bridge decided against placing inflexible rules upon recovery and held that '...to make the defendant liable for reasonably foreseeable psychiatric illness caused by his negligence' would not be imposing a crushing burden on him out of proportion to his moral responsibility. ${ }^{41}$ He pointed out that '...to draw a line by reference to any [strict rules] must impose a largely arbitrary limit of liability. ${ }^{42}$ He was the most liberal of the Lords and he summed up his position aptly - '... if asked where the thing is to stop, I should answer... where in the particular case, the good sense of the judge, enlightened by progressive awareness of mental illness, decides. $^{43}$ Needless to say, television viewers are unlikely to be barred under this approach merely because they were not at the scene. Undoubtedly, this criterion provides little certainty but appears to be in the spirit of developing the common law.

\footnotetext{
${ }^{38}$ Ibid 430 .

${ }^{39}$ Ibid 431.

${ }^{40}$ Michael Jones, 'Liability for Psychiatric Illness - More Principle, Less Subtlety?' (1995) 4 Web

Journal of Current Legal Issues 1. <http://webjcli.ncl.ac.uk/article4/jones4.html>

${ }^{41}$ McLoughlin v O'Brian (1983) 1 AC 410, 441.

${ }^{42}$ Ibid 442 .

${ }^{43}$ Ibid 443 .
} 
Whilst there was some judicial support for recovery by television viewers, the 'control mechanisms' of Lord Wilberforce do not appear to favour such an approach. If his approach was adopted television viewers would be unlikely to recover despite the fact that his Lordship did not close the door on such claimants. Since ensuing cases adopted the control mechanisms in one form or another, recovery is unlikely unless the claimants arrived at the 'immediate aftermath' of the crash.

The first High Court case to consider McLoughlin in Australia was Jaensch. ${ }^{44}$ The facts of Jaensch are somewhat similar to McLoughlin. The respondent's (Mrs Coffey) husband suffered serious injury through the negligence of Mr Jaensch. Mrs Coffey was not present at the scene of the accident but arrived at the hospital soon after. She developed psychiatric illness through what she saw and heard at the hospital. She was allowed recovery by the High Court.

Chief Justice Gibbs interpreted McLoughlin as '...part of the logical progression of the development of the law already evidenced in the earlier authorities and correct in principle. ${ }^{45}$ According to His Honour, the law had been removing '...the old and irrational limitations...' one by one and McLoughlin had advanced it one step further. With regards to the three elements, he stated - "I would with respect, reserve my opinion as to the correctness of some of Lord Wilberforce's comments... in particular on his statement that there must be a close proximity in space as well as in time and that 'the shock must come through sight or hearing of the event or of its immediate aftermath. The law must continue to proceed in this area step by cautious step. ${ }^{46}$ Whilst his Honour required more than foreseeability he was unwilling to be bound by unnecessary and inflexible rules that would hamper development. This is a step closer to accepting liability for claimants who suffer 'nervous shock' as a result of watching distressing events on television, if they are in a close relationship with the immediate victim.

In a short judgment, Justice Murphy allowed recovery, stating as his main reason that "in the absence of legislation limiting recovery, I am not satisfied that there are acceptable reasons of public policy for limiting recovery here." ${ }^{, 4} \mathrm{He}$ did not discuss the Lord Wilberforce factors and he did not expressly approve them.

Justice Brennan took a broadly similar approach and discussed in great detail public policy. He said that on his wide interpretation - 'the thing will stop where good sense in the finding of facts stops it. ${ }^{, 4}$ He defined 'shock as':

\footnotetext{
${ }^{44}$ (1984) 155 CLR 549.

${ }^{45}$ Ibid 552.

${ }^{46}$ Ibid 555

${ }^{47}$ Ibid 558 .

${ }^{48}$ Ibid 572
} 
...the sudden sensory perception - that is by seeing, hearing or touching of a person, thing or event, which is so distressing that the perception of the phenomenon affronts or insults the plaintiff's mind and causes a recognisable psychiatric illness. A psychiatric illness induced by mere knowledge of a distressing fact is not compensable; perception by the plaintiff of the distressing phenomenon is essential. ${ }^{49}$

His Honour concluded thus:

The limitations suggested by Lord Wilberforce....are appropriately taken into account by the general principles of causation and reasonable foreseeability. There are no other elements which might preclude a duty of care arising where the kind of damage caused by a defendant's conduct is shock-induced psychiatric illness and that kind of damage is reasonably foreseeable. ${ }^{50}$

Despite leaving the class and the definition of aftermath open, ${ }^{51}$ His Honour recognised that it would be in exceptional cases that persons outside the close relationship, ${ }^{52}$ not directly perceiving the event or its immediate aftermath, ${ }^{53}$ would result in recovery. He said:

...when the scene of an accident is left behind, and the perception of some later phenomenon induces psychiatric illness...the factual difficulties in the way of establishing negligence occasioning nervous shock are greatly increased. $^{54}$

It appears that a secondary victim may recover provided they perceive the primary victim in their post-accident 'distressing appearance' and that appearance would fairly be regarded as the result of the defendant's carelessness or the reasonably foreseeable result of it. ${ }^{55}$ As far as our claims are concerned, unless a television viewer arrives at the immediate aftermath of the distressing events that they viewed on television, they will be unable to recover.

On the other hand, Justice Deane set out additional proximity requirements, ${ }^{56}$ but he did not expressly restrict recovery to the 'Wilberforce principles'. He required presence at the scene or immediate aftermath. ${ }^{57}$ The preferable view would seem to be that a person who has suffered reasonably foreseeable psychiatric injury as the result of contemporaneous observation at the scene of the accident is within the area

\footnotetext{
${ }^{49}$ Ibid 567

${ }^{50}$ Ibid 577.

${ }^{51}$ Ibid 570

52 Ibid.

53 Ibid.

54 Ibid.

${ }^{55}$ Ibid 577

${ }^{56}$ Ibid 585, 586.

${ }^{57}$ Ibid 605, 606.
} 
which the common law accepts that the requirement of proximity is satisfied...regardless of his particular relationship with the injured person.

According to His Honour, the aftermath extends to '... wherever sound may carry and to wherever flying debris may land.' 'In a modern society, the aftermath also extends to the ambulance taking an injured person to hospital for treatment and to the hospital itself during the period of immediate post-accident treatment. ${ }^{58}$ Unless the television viewer is able to attend the 'immediate aftermath' he/she will be unable to recover. His Honour did however concede that 'communicated nervous shock' might be recoverable.

It is somewhat difficult to discern an acceptable reason why a rule based on public policy should preclude recovery for psychiatric injury sustained by a wife and mother who is so devastated by being told on the telephone that her husband and children have all just been killed that she is unable to attend at the scene; while permitting recovery for the reasonably, but perhaps less readily, foreseeable psychiatric injury sustained by a wife who attends at the scene of the accident or its immediate aftermath at the hospital where her husband has suffered serious but not fatal injuries. 59

Whilst his Honour did not see the necessity to deal with the issue further in the present case, his judgment creates the best hope for recovery.

Finally, Justice Dawson embraced the limits set by Lord Wilberforce - '...in order to be compensable, nervous shock must not only be reasonably foreseeable; it must also fall within bounds set as a matter of policy. See McLoughlin v O'Brian per Lord Wilberforce at pp. 420-422. ${ }^{, 60}$

What are the conclusions one can draw from Jaensch as far as the television claimants are concerned? Other than Deane J, Murphy J (who did not adopt the Wilberforce principles), and perhaps Brennan $\mathrm{J}$ through his foreseeability/causation approach, no other judge appears to have given support to recovery for 'communicated nervous shock'. All others have imported some limitations, although most refer to them as 'factors' to be taken into account. Having taken these factors into account, television viewers are unlikely to recover under the principles of this case unless simultaneous broadcasts are held to be a 'direct perception' of the event or its immediate aftermath. This approach differentiates between victims on the basis of where they were and by assuming, without the support of medical evidence, that presence at the scene was more likely to cause psychiatric illness than the communication of the distressing news. Until Annetts and Gifford such an approach was judicially accepted and would have ruled out our 'television claimants'.

\footnotetext{
${ }^{58}$ Ibid 607, 608 .

${ }^{59}$ Ibid 608, 609 .

${ }^{60}$ Ibid 613
} 
In Annetts and Gifford, the High Court of Australia explored the status of the 'control mechanisms' in the law of negligence, as it stands today. These two cases appear to have breathed life into the possibility of success by the television claimants. Whilst these two cases are vital to this paper, it is important to first discuss the House of Lords decision in the litigation following the Hillsborough stadium disaster in the UK. The facts of Alcock necessitated the consideration of recovery by claimants who suffer nervous shock from communication of the distressing event through the medium of television.

\section{AlCOCK - WILL THE CoURTS ACKNOWLEdGe Recovery?}

The House of Lords in Alcock generally adopted the limitations upon recovery placed in McLoughlin by Lord Wilberforce and some were less liberal in their application of the principles. The Law Lords introduced the three control mechanisms as factors to be considered in addition to foreseeability. This is especially true of Lord Keith, ${ }^{61}$ Lord Ackner, ${ }^{62}$ Lord Oliver, ${ }^{63}$ and Lord Jauncey. ${ }^{64}$ It is important to note however that whilst some Law Lords discussed the factors as part of reasonable foreseeability, others saw them as controls operating in addition to foreseeability.

Lord Wilberforce had regarded the three elements as tests of foreseeability rather than further factors to be satisfied. ${ }^{65}$ Of more importance is the refusal by the House of Lords to allow television viewers to recover for psychiatric illness. We will now discuss the facts of Alcock and then discuss the plight of our claimants.

The claims were for psychiatric injury suffered by close relatives (i.e. siblings, children, and some less close relationships such as a fiancé and grandparents) of some of those who perished at the Hillsborough Stadium disaster during a soccer match. Of particular relevance to our discussion are the secondary victims who viewed the events as they unfolded on simultaneous television broadcast. None of the claimants were successful for various reasons and the reasons for denial are an important guide for 'television claimants'.

According to Lord Keith, the viewing of television broadcasts could not be '...equiparated with the viewer being within sight or hearing of the event or its immediate aftermath.' He added - '...nor can the scenes reasonably be regarded as giving rise to shock, in the sense of sudden assault on the nervous system. ${ }^{66}$ This

\footnotetext{
${ }^{61}$ Ibid 396.

${ }^{62}$ Ibid 400

${ }^{63}$ Ibid 406

${ }^{64}$ Ibid 419

${ }^{65}$ Segal and Williams, above n 26, 108.

${ }^{66}$ Alcock v Chief Constable of South Yorkshire Police [1992] 1 AC 310, 398.
} 
was because none of the scenes depicted suffering of recognisable individuals, as the broadcasting code of ethics excluded such broadcasts and this state of affairs was known to the defendant. ${ }^{67}$ His Lordship also held that there was no evidence of close ties of love and affection in the relationships in the case (i.e. of brother and brother-in-law). ${ }^{68}$ This was despite him not having limited the class of persons who may come within such a close relationship and considering the 'Wilberforce rules' as only factors to be taken into account. ${ }^{69}$ Hence, it appears as though claimants who suffer 'nervous shock' from viewing a broadcast may recover if 'suffering by recognisable individuals' was depicted and the broadcasting guidelines did not bar such pictures. As Des Butler has pointed out however, to base 'nervous shock' claims on broadcasting ethics is absurd, to say the least. ${ }^{70}$

This was the same line of reasoning adopted by Lord Jauncey. His Lordship added:

...a television programme such as that transmitted from Hillsborough involves cameras at different viewpoints showing scenes all of which no one individual would see, edited pictures and a commentary superimposed. I do not consider that such a programme is equivalent to actual sight or hearing at the accident or its immediate aftermath. ${ }^{71}$

He, nevertheless, refused to comment on the Nolan L.J example of children in a balloon (explained below), except to say '...to essay any comprehensive definition would be a fruitless exercise. ${ }^{72}$ As Des Butler has argued, the camera angles do not necessarily lessen the impact upon a viewer. A zoom view, different angle or commentary may render the events more horrific for a television viewer than a percipient witness in another part of a ground relying on the naked eye. ${ }^{73}$

Lord Ackner also held that the claimants could not recover because of the code of ethics. $^{74}$ On a positive note, however, his Lordship did not rule out the possibility that simultaneous television broadcasts may be equated with "sight or hearing of the event or its immediate aftermath." "75 He cited the example, given by Nolan L.J in the Court of Appeal, where recovery may be allowed. This involved the simultaneous broadcasting of a special event of children travelling in a balloon, being watched by adoring parents, and the balloon suddenly bursting into flames. ${ }^{76} \mathrm{He}$ further noted that "many other such situations could be imagined where the impact of the simultaneous television pictures would be as great, if not greater, than the

\footnotetext{
${ }^{67}$ Ibid.

${ }^{68}$ Ibid.

${ }^{69}$ Ibid 397.

${ }^{70}$ Des Butler, 'Nervous Shock at Common Law and Third Party Communications: Are Australian Nervous Shock Statutes at Risk of Being Outflanked?' (1996) 4 Torts Law Journal 120.

${ }^{71}$ Alcock $v$ Chief Constable of South Yorkshire Police [1992] 1 AC 310, 423.

${ }^{72}$ Ibid.

${ }^{73}$ Butler, above n 70, 120.

${ }^{74}$ Alcock v Chief Constable of South Yorkshire Police [1992] 1 AC 310, 405.

${ }^{75}$ Ibid.

${ }^{76}$ Ibid.
} 
actual sight of the accident." 77 His Lordship refused to place limitations on the 'close relationship' class, ${ }^{78}$ although he did not allow siblings to recover (because they could not prove love). ${ }^{79}$ If the claim by a person who lost two brothers in circumstances as horrifying as those in the Hillsborough disaster was unsuccessful, it is difficult to envisage recovery by someone other than a parent or spouse. ${ }^{80}$

Lord Oliver handed down a separate but almost identical decision to that of Lord Ackner, at least in relation to the television viewers. ${ }^{81}$ Despite the harshness of the actual decision there is a silver lining, at least for close relatives who view events as they unfold on television. Lords Ackner and Oliver did not completely bar recovery by television viewers. Nevertheless, given that the viewing of people crushed in a stadium disaster was not horrific enough for their Lordships, it is difficult to assess what would actually be sufficient. Perhaps a plane crash would be sufficient but even then the Law Lords appear to require direct perception of suffering by 'recognisable individuals'.

\section{The Reactions to AlCock}

The Alcock decision was widely criticised both in Britain and Australia. Unfortunately such fervent criticism did not alter general judicial attitude to nervous shock. The case of White ${ }^{82}$ demonstrated an unwillingness to depart from Alcock. This was especially reflected by Lord Steyn, who at one point said - 'the abolition or relaxation of the special rules governing the recovery of damages for psychiatric harm would greatly increase the class of persons who can recover damages in tort. ${ }^{83}$

In Britain the most notable attack came from the UK Law Commission. ${ }^{84}$ The central recommendation of the Commission was that the law must abandon the requirements of "closeness in time and space" and "shock." It is clear that the Commission was persuaded by the arbitrary nature of judicial decisions based on these control mechanisms and upon the basis of advice received regarding causation

\footnotetext{
${ }^{77}$ Ibid.

${ }^{78}$ Ibid 404.

${ }^{79}$ Alcock v Chief Constable of South Yorkshire Police [1992] 1 AC 310, 406.

${ }^{80}$ K J Nasir, 'Nervous Shock and Alcock: The Judicial Buck Stops Here' (1992) 55 Modern Law Review 705 .

${ }^{81}$ Alcock v Chief Constable of South Yorkshire Police [1992] 1 AC 310, 416-417.

${ }^{82}$ White v Chief Constable of South Yorkshire Police [1999] 2 AC 455. By a majority of four to one, Lord Griffith dissenting, the House of Lords held that a rescuer may only recover for pure psychiatric injury if he/she is actually exposed to physical danger or reasonably believes he/she is in such danger. This decision appears to return the position of rescuers to what it was in 1901 following Dulieu $v$ White [1901] 2 KB 669. It also contradicts the often approved authorities of Chadwick $v$ British Railways Board [1967] 1 WLR 912 and Mount Isa Mines v Pusey (1970) 125 CLR 383, where the courts held that a rescuer may recover even if he/she was not in direct physical danger.

${ }^{83}$ White $v$ Chief Constable of South Yorkshire Police [1999] 2 AC 455, 541-2.

${ }^{84}$ United Kingdom, above n 31, 6.10.
} 
and psychiatric injury. ${ }^{85}$ Whilst the Commission proposed to remove these restrictions through legislation, it was unwilling to abandon the requirement of 'reasonable foreseeability'. It rejected the approach taken in three Australian states, which did not require such a requirement once the relationship in the statute had been satisfied. $^{86}$

The requirement of 'close ties of love and affection' was however preserved. The Commission recommended that it should be given statutory footing because certain circumstances would give rise to an irrebuttable presumption that a relationship is close enough to result in psychiatric injury. Spouse, parent/child, sibling, and cohabitant of two years or more (including homosexual cohabitants) came within such a relationship. The Commission did not specifically exclude other relationships, so recovery may be possible if a close tie of love and affection were to be proved. The Commission did make further recommendations but they will not be discussed given the limitations of this paper.

It is interesting to note that these recommendations have not as yet been given statutory footing. If they were to be legislated, it is likely that recovery for 'communicated nervous shock' would be allowed in the UK. Bystanders however are unlikely to be able to prove a close tie of love and affection and are therefore unlikely to recover. Even if these recommendations are adopted, the "code of ethics' reasoning offered by the House of Lords may still place the recovery by television viewers at issue.

Des Butler, in Australia, has provided four reasons which undermine the 'Code of Ethics' argument espoused by their Lordships in Alcock, and bolster the case for recovery by television viewers. ${ }^{87}$ First, it is dangerous, '...to place such reliance upon the Code of Ethics for the purposes of devising limitations of liability in effect amounts to an abdication of the determination to an outside body. ${ }^{88} \mathrm{He}$ asks where the law would be if the Broadcasting authority decides to change the code of ethics.

Second, breach of the code of ethics may not always amount to a novus actus interveniens, especially if 'it is the very kind of occurrence that might be expected to happen'. Mr Butler quite correctly argues that in '...the modern days of keen competition between media operators, it is not unusual to expect broadcasters to breach the Code of Ethics from time to time. ${ }^{89}$ Certainly applying the statutory test for duty of care, it is not an 'insignificant risk'. 90

\footnotetext{
${ }^{85}$ Ibid.

${ }^{86}$ Kay Wheat, 'Liability for Psychiatric Illness - The Law Commission Report' (1998) Journal of Personal Injury Litigation 211.

${ }^{87}$ Butler, above n 70, 120

${ }^{88}$ Ibid 128.

${ }^{89}$ Ibid.

${ }^{90}$ Wrongs Act 1958 (Vic) s 48; Civil Liability Act 2002 (WA) s 5B; Civil Liability Act 2002 (Tas) s 11; Civil Liability Act 2003 (Qld) s 9; Civil Liability Act 2002 (NSW) s 5B; Civil Law (Wrongs) Act 2002 (ACT) s 43; Civil Liability Act 1936 (SA) s 32.
} 
Third, even a broadcaster complying with the Code may still inadvertently broadcast 'suffering by recognisable individuals'. It is clear from the judgments that the main reason for the claims by television viewers failing was because such suffering was not broadcast. One of the examples he provides as an inadvertent breach is where a person is identifiable by the role played in the incident, such as where the camera is following the progress of a particular car during a motor race, which due to the negligence of a mechanic is involved in an accident.

Finally, Mr Butler points out, that a particular event may be broadcast live all over the world and the foreign country's Code of Ethics, if there is one, may be different to the country in which the broadcast is filmed. This places further doubt over the validity of the 'Alcock' reasoning, especially given that their Lordships did not limit the class of persons who may prove a 'close relationship' to the primary victim and a majority were willing to allow recovery in some horrific cases. Moreover, the Australian cases have focused on the relationship between the tortfeasor and the secondary victim, as compared to the English cases, which have relied on the relationship between the primary and the secondary. ${ }^{91}$

The door may not have been completely slammed in the face of recovery for psychiatric injury based on television broadcasts, especially given that some believed the Alcock decision addressed the incapability of the law to deal with injuries on a mass scale. ${ }^{92}$ Whilst the case of Alcock was somewhat detrimental to claims by television viewers the Australian High Court cases of Tame and Annetts and Gifford, and Statutes in Australian States, have given some hope of recovery.

\section{AnNetTs And Gifford - The Pendulum Swings}

The facts of Annetts ${ }^{93}$ will be considered before embarking on a discussion of this somewhat confusing decision. Mr \& Mrs Annetts agreed to send their 16-year-old son, James, to work as a jackaroo, on the assurance of the employer (Australian Stations) that James would work under constant supervision. This promise was not kept and James was sent to work alone $100 \mathrm{~km}$ away (near Halls Creek). After three months the manager learnt that James had disappeared and suspected that he was in grave danger of injury or death. Three days later, on being told of James' disappearance on the telephone by a police officer, Mr Annetts collapsed. James's parents made several trips to Halls Creek and some of his belongings were found in extensive searches that were carried out following James's disappearance. Five months later, his body was found in the desert. He had died of dehydration, exhaus-

\footnotetext{
${ }^{91}$ Ibid.

${ }^{92}$ Peter Handford and Nicholas J Mullany, Tort Liability for Psychiatric Damage - The Law of Nervous Shock (1993) 6.

${ }^{93}$ The facts of Tame and the decision by the High Court in that matter are not directly relevant to this discussion and will not be addressed.
} 
tion and hypothermia, when his vehicle broke down. Mr and Mrs Annetts suffered psychiatric illness upon hearing that James had disappeared and later when told of his death.

Each of the judgments will now be analysed to support the contention that television viewers are not completely excluded from recovery for 'nervous shock', at least where there exists a 'special relationship'. Chief Justice Gleeson stated that the 'Wilberforce controls' should not be applied inflexibly. ${ }^{94}$ Contrary to previous authority, he held that the tests were only factors to be considered rather than determinative of the issue. ${ }^{95}$ Gleeson CJ, however, did not deal with the class of persons who would be allowed recovery. His Honour appeared to emphasise the relationship between the plaintiff and the defendant rather than the relationship between the plaintiff and the injured person. ${ }^{96}$ He did however state that the relationship between the claimant and the injured was not relevant to Annetts because it concerned parent/child relationship (long accepted class for recovery). ${ }^{97}$

Justice Gaudron appeared to cast serious doubts over the status of the 'control mechanisms' as preconditions to recovery. ${ }^{98}$ Like Gleeson CJ, she views the complete abolition of control factors other than 'foreseeability' as dangerous. ${ }^{99}$ Despite leaving the door open to the possibility of recovery for 'told nervous shock' she indicated that the 'direct perception' rule would be relevant unless there was a special relationship between the potential litigants. ${ }^{100}$ She did not limit the special relationships. ${ }^{101}$

Her Honour however refused to rule out recovery by a class of people other than those having a close tie of love and affection with the immediate victim. Having identified the tests for recovery in Jaensch, which included recovery for those in close relationships, she goes on to say that 'to treat those...identified in Jaensch $v$ Coffey as the only persons who may recover for negligently caused psychiatric harm is...productive of anomalous and illogical consequences.' ${ }^{, 22}$ As a result, those in not so close relationships may not be excluded from recovery merely because they are not in a traditional relationship of close love and affection.

Justice McHugh, on the other hand, held it was unnecessary to examine the status of the three prerequisites. ${ }^{103} \mathrm{He}$ nevertheless stated that there was no need to satisfy additional requirements if there was a pre-existing relationship. ${ }^{104}$ This is in line

\footnotetext{
${ }^{94}$ Annetts (2002) 211 CLR 317, 333 and 337.

95 Ibid.

96 Ibid.

${ }^{97}$ Ibid 338

${ }^{98}$ Ibid 338, 339, 340 and 344.

${ }^{99}$ Ibid 338 .

${ }^{100}$ Ibid 339, 340.

${ }^{101}$ Ibid.

102 Ibid 340.

${ }^{103}$ Ibid 364

${ }^{104}$ Ibid.
} 
with his rejection of proximity as an additional test to foreseeability. ${ }^{105}$ He places a different duty upon the employee/employer relationship and like Justices Gaudron and Gleeson appears to embrace the need for a pre-existing relationship. ${ }^{106}$ His Honour does not, however, shed any further light on this issue.

His Honour does not pay much attention to the class of claimants who may recover. He appears to have isolated this case as one arising from employer/employee relationship. Perhaps this was not the appropriate case to define "close ties of love and affection' given that the parent/child relationship has long been recognised as worthy of recognition. Any such discussion would not have been central to the issue at hand. His Honour however took the opportunity to be more expansive in Gifford.

Justices Gummow and Kirby, in a joint judgment, held that it was time for reaccommodation of the competing interests that are in play in nervous shock cases, given the advances in medicine which have allowed for recognition of genuine cases. ${ }^{107}$ Their Honours succinctly state the status of the three rules in Australian nervous shock law - "none of these three control mechanisms has been accepted by this court as a pre-condition to liability for negligently inflicted psychiatric harm."108 Throughout their judgment there is a sustained and fervent attack upon the three rules. ${ }^{109}$ This is perhaps the most favourable judgment of all given its interpretation of Alcock, which if accepted in Australia may bar recovery for television viewers. They identify the lack of direct perception in Alcock as the reason for the English court denying recovery to the claimants who suffered on account of viewing the events on television. ${ }^{110}$ Based on this interpretation of Alcock, a television claimant is likely to recover because their Honours reject the 'direct perception' rule as a precondition, on the basis that it produces inconsistent and inequitable results. 111

Justice Hayne discusses in detail the pros and cons of the three rules and their application. He defines the three rules somewhat differently to the other judges (i) limits on the class of persons who may recover (ii) shock or sudden sensory perception and normal fortitude, and (iii) allowing for only psychiatric harm rather than emotional distress. ${ }^{112} \mathrm{He}$ regards the second limit as a factor but not a precondition, but acknowledges the dangers of accepting reasonable foreseeability as the sole test of recovery. He sees the need for 'some control mechanisms, beyond foreseeability of psychiatric harm... ${ }^{113} \mathrm{He}$ held that 'normal fortitude' and the distinction between psychiatric injury and emotional distress were the most impor-

\footnotetext{
${ }^{105}$ Ibid 356-7.

${ }^{106}$ Ibid 357.

${ }^{107}$ Ibid 378

${ }^{108}$ Ibid 380

${ }^{109}$ Ibid 380, 381, 386 and 394.

${ }^{110}$ Ibid 391, 392.

${ }^{111}$ Ibid.

${ }^{112}$ Ibid 404.

${ }^{113}$ Ibid 410.
} 
tant control mechanisms and refused to abandon them. ${ }^{114}$ He further refused to treat physical and psychiatric injuries differently. ${ }^{115}$

Finally, Justice Callinan summarised 'nervous shock' law, ${ }^{116}$ and appears to have extended the aftermath rule to include situations where the news is "communicated to [the plaintiff] as soon as reasonable practicable, and before he or she has or should reasonably have reached a settled state of mind about it." This is likely to include viewers who watch the events unfold on live television. This was however subject to a qualifying factor, which was the requirement of a special or close relationship between the tortfeasor, the claimant and the primary victim. The $A n$ netts case was seen to be an example of this special relationship. Given that a close relationship needs to exist between the primary victim and the plaintiff, it is unlikely that bystanders will be able to recover although there have been no limits placed on such a class. Furthermore, the decision is unclear as to whether a relationship other than that in Annetts would suffice.

The Annetts decision has been clarified by the decision of Gifford ${ }^{117}$ and we now turn to that case for further assistance. It is important to note that this case was decided by six judges rather than seven in Annetts, given the retirement of Justice Gaudron. The facts of Gifford were stated in Chief Justice Gleeson's judgment. It involved the death of Mr Gifford, who was crushed to death by the negligence of his employer (Strang). At the time the appellants (Mr Gifford's children) were teenagers and were informed of the death later on the same day. They did not witness the accident or its immediate aftermath. Similar to Annetts therefore this is a case of 'told nervous shock.' Whilst not relevant to our discussion, Mr Gifford's ex-wife failed in her claim for nervous shock, under s 4(1) (b) of the Law Reform (Miscellaneous Provisions) Act 1944 (NSW), because she was held not to have suffered any psychiatric injury. Her appeal failed. Her children also failed at first instance and at the Court of Appeal. Both these decisions were handed down before Annetts. They did, however, succeeded in their appeal under common law (they did not come under the statutory provisions, to be discussed later), following the decision in Annetts.

Chief Justice Gleeson held that the three 'control mechanisms' should be considered as factors rather than preconditions. ${ }^{118}$ Once again the pre-existing relationship between the plaintiff and the defendant was determinative of the issue. ${ }^{119}$ As far as the class is concerned, he utilised policy to justify the recognition of the parent/child relationship as prima facie satisfying a close and intimate relationship. ${ }^{120}$

\footnotetext{
${ }^{114}$ Ibid 410, 414.

${ }^{115}$ Ibid 410.

${ }^{116}$ Ibid 439.

${ }^{117}$ Gifford (2003) 214 CLR 269.

118 Ibid 276.

${ }^{119}$ Ibid.

${ }^{120}$ Ibid 276 and 277.
} 
Similarly, Justice McHugh declared that since Annetts, common law liability might exist in the absence of direct perception of the distressing event or its immediate aftermath. ${ }^{121}$ The central question according to his Honour is whether the claimants are neighbours in the Atkinian sense of that term. ${ }^{122}$ The determination of this issue depends on '.. whether the plaintiffs were so closely and directly affected by the tortfeasor's relationship with the primary victim that the tortfeasor ought reasonably have them in contemplation when it directed its mind to the risk of injury to which it exposed the primary victim.' ${ }^{123}$ His Honour held that the answer to this question lay in the nature of the relationship between the plaintiffs and the primary victim (contrast this with Gleeson CJ, who held that the relevant relationship was that between the plaintiff and the defendant). ${ }^{124}$ It is also interesting to note that His Honour held that '...a duty to take care may exist even though the primary victim and the person suffering psychiatric harm had no pre-existing relationship. ${ }^{125}$ One can therefore draw the conclusion that the class of claimants is not necessarily closed.

His Honour's view appears to have expanded the class of possible plaintiffs since his decision in Annetts. Whilst not attempting to define the relationships which are characterised by that 'closeness', he allows for a case by case approach. 'Whether such a relationship exists in a particular case will often be a matter of evidence although...in some cases the nature of the relationship may be such that it may be presumed. ${ }^{126}$ With regards to presumed relationships of love and affection he cites with approval the passage by Lord Keith of Kinkel in Alcock, where his Lordship provides as examples family relationships and close friendships. ${ }^{127}$ Justice McHugh also provides further examples of his own, such as parent and child, husband and wife, sibling and sibling, de facto partners and engaged couples. ${ }^{128}$ He goes on to say, 'no doubt the parties to such relationships may sometimes be estranged'. ${ }^{29}$ Despite this possibility, however, so commonly are these relationships close and loving that a wrongdoer must always have such persons in mind as neighbours. To require such persons in such relationships to prove the closeness and loving nature of the relationship would be a waste of curial resources in the vast majority of cases. What is even more comforting is his next statement - '...the wrongdoer must always have in mind any person who can establish a close and loving relationship with the person harmed. ${ }^{, 130}$ Despite having provided a detailed discussion, his Honour qualifies his statement - 'Although a close relationship with the person harmed brings a person with the neighbour concept, it is not a necessary condition of that concept.' 131

\footnotetext{
${ }^{121}$ Ibid 288.

122 Ibid.

${ }^{123}$ Ibid.

${ }^{124}$ Ibid 290.

125 Ibid.

${ }^{126}$ Ibid 289.

${ }^{127}$ Ibid 288, 289.

${ }^{128}$ Ibid.

${ }^{129}$ Ibid.

${ }^{130}$ Ibid.

${ }^{131}$ Ibid 290.
} 
Whilst it is interesting to ponder whether Lord Atkin intended such a wide interpretation of his test to include 'communicated nervous shock', Justice McHugh appears to indicate that the area of nervous shock will be given wider application in the future. It is also fascinating to note that his Honour, like the rest of the bench, found that an employer owed a duty of care to the children of an employee to provide a safe place of employment for the employee. ${ }^{132}$

According to Justices Gummow and Kirby, Annetts determined that 'liability ...does not depend upon satisfaction of an absolute requirement that a plaintiff 'directly perceive' the relevant distressing incident or its "immediate aftermath.", 133 It did not however '...follow that a duty arises in all circumstances to which the control mechanism previously has been said to attach. Indeed, it would be quite wrong to take it from Tame and Annetts that reasonable foreseeability of mental harm is the only condition of the existence of a duty of care. ${ }^{134}$

Justice Hayne's judgment was along similar lines to the other judgments in that he interpreted Annetts as having decided that the lack of perception of a traumatic event is not fatal to a claim. ${ }^{135}$ Unlike others, however, he did not attempt to discuss what the factors should be except to note that new ones must replace the old controls. ${ }^{136}$ His reasons for imposing a duty upon the employer were similar to that of Justices Gummow and Kirby. ${ }^{137}$ In other words, he felt that control and vulnerability were required on top of reasonable foreseeability and those were the determinative factors in Gifford. ${ }^{138}$ A closer reading of Hayne J's judgment suggests that he felt bound by the Annetts decision to uphold a duty of care ${ }^{139}$ and it seems quite clear that the closeness of relationship between employer and employee and between children and employee were influential factors. ${ }^{140}$ Regardless it is interesting to note the evolution of a wholesale test, which was not evident in Annetts. Provided that the bystanders can prove direct perception and establish love and affection (although doubtful) they may also be allowed to recover.

Finally, Justice Callinan clearly said that he would '...adhere in this case to what [he] said in Tame.'141 Given that his decision in Annetts has already been discussed there is no need for further discussion, except to say that he would only remove the three control mechanisms provided there was a pre-existing relationship.

\footnotetext{
132 Ibid 291.

${ }^{133}$ Ibid 294.

${ }^{134}$ Ibid 295.

${ }^{135}$ Ibid 303, 304.

${ }^{136}$ Ibid.

${ }^{137}$ Ibid.

${ }^{138}$ Ibid 305.

${ }^{139}$ Ibid.

${ }^{140}$ Ibid.

${ }^{141}$ Ibid 310.
} 


\section{CONCLUSIONS FROM ANNETTS AND GIFFORD}

According to Justice Gleeson, in Annetts and Gifford, it is clear that plaintiffs who base their nervous shock claims on injury or death to an employee of the tortfeasor are likely to recover, provided that they are in a close relationship with the victim. Recovery by television viewers may not however be so clear-cut. First, His Honour held that the reason for establishing a duty of care was the existence of a preexisting duty between the plaintiffs and the defendant (the plaintiffs' son was employed by the defendant who had given an assurance to look after their son). ${ }^{142}$ Whilst it remains to be seen whether this would be a precondition to recovery for nervous shock, it appears as though it will at least be a key factor from Annetts and the recent case of Gifford. Second, Gleeson CJ declared that the outcome of the case did not rely upon the so-called control mechanisms of 'sudden shock' and 'direct perception' or 'immediate aftermath.' Consequently, the statements by Gleeson CJ regarding the controls should be treated as obiter rather than the basis of a communicated nervous shock claim. Direct perception of the incident is unlikely to be satisfied by television broadcasts, even simultaneous live broadcasts as in Alcock. Yet the fact that His Honour has demonstrated a willingness to abandon the strict rules implies that these claims are not necessarily doomed to fail.

Justice Gaudron was reluctant to abandon the direct perception rule and this may mean that claimants, who watch events as they unfold on television, will not succeed in their claim. She was however willing to make an exception where a special relationship exists between the claimant and the tortfeasor. As will be evident when the statutes are discussed, once a 'family relationship' is established, the road to recovery will be less troublesome as the 'direct perception' will become a factor to be considered rather than a precondition.

Justice Hayne's approach leaves open the possibility of recovery, although one needs to be aware of his qualifying statements. ${ }^{143}$ He required more than reasonable foreseeability and the pre-existing relationship between the plaintiff and defendant was a decisive factor. ${ }^{144} \mathrm{He}$ has elevated the relationship (between an employer and an employee's family) in Annetts to one akin to employer/employee. ${ }^{145}$ Provided there is a close relationship recovery is highly likely, especially given that His Honour did not require presence at the scene.

Whilst Justices Gummow and Kirby rejected 'direct perception' as a precondition, there are two reasons why not all claims by television viewers are likely to succeed. First, the justices indicated that although the three rules are no longer determinative of liability, ${ }^{146}$ they are still relevant factors as greater than foreseeability is re-

\footnotetext{
${ }^{142}$ Annetts (2002) 211 CLR 317, 337.

${ }^{143}$ Ibid 413.

144 Ibid 419, 420 .

145 Ibid.

${ }^{146}$ Ibid 394.
} 
quired. ${ }^{147}$ Second, the antecedent relationship between the claimant and defendant was the decisive factor. ${ }^{148}$ In other words, absent direct perception and sudden shock or a pre-existing relationship between the tortfeasor and the claimants, the claimants are unlikely to recover. Their Honours did not make a definitive decision on the class of persons that may recover, indicating a preference for a flexible and case-by-case approach. Additionally, they did not expressly exclude recovery by bystanders or restrict recovery to relationships arising out of the employer/employee relationships.

Justice Callinan's decision also appears to favour recovery provided there is a special relationship. Whilst he considered the requirement of a 'special relationship' as a necessary element for recovery, he extended the immediate aftermath to include communication of news. His Honour was of the opinion that the communication must occur before the claimant reasonably reaches a settled state of mind and the communication must occur as soon as reasonably practicable. Although live telecast may suffice, replays are unlikely to be considered sufficient.

Finally, Justice McHugh took the opportunity to be more expansive in Gifford and did not exclude liability for communicated nervous shock. He did however, like the others, place high emphasis on the relationship between the plaintiff and the primary victim.

On the whole, whilst they were willing to keep an open mind to the possibility of recovery in all cases by removing inflexible rules, their Honours were careful not to expand the area of nervous shock without reason. They required something more than mere foreseeability and in Gifford it presented itself in several forms. They included policy (which included the protection of the young from serious harm), ${ }^{149}$ and control of the circumstances, and therefore the risk of harm, by the employer and complete vulnerability of the children in being unable to protect themselves against the risk of psychiatric harm. ${ }^{150}$ In effect, this is similar to the 'proximity' factors required for breach of duty by a statutory authority. Their Honours appeared to be persuaded by the close relationships in both cases, clearly evincing an intention that a 'close tie of love and affection' is an important factor, to at least be considered. The claimants in Klein were certainly in a close relationship with the victim and the fact that all except one of the plaintiffs were not at the scene may not be detrimental to their claim.

As Associate Professor Danuta Mendelson has noted, the Australian courts have been reluctant to place arbitrary limits upon the categories of claimants. ${ }^{151}$ In fact, the High Court has indicated a willingness to look at the matter on a case by case basis without closing the door forever on recovery by television viewers. Perhaps it

\footnotetext{
147 Gifford (2003) 214 CLR 269, 276.

${ }_{148}$ Annetts (2002) 211 CLR 317, 397 and 398.

${ }^{149}$ Gifford (2003) 214 CLR 269, 299, 300 and 301.

${ }^{150}$ Ibid 301.

${ }^{151}$ Mendelson, above n 5, 222.
} 
is also appropriate to add that the High Court has taken on a more traditional role, that of developing the law upon a basis of "logical necessity", ${ }^{152}$ the approach abandoned since the McLoughlin case, when it came to considering psychiatric injury cases. Despite evidencing a more expansive approach to recovery for nervous shock, the High Court failed to provide an authoritative guide to the legal position in Australia. ${ }^{153}$

\section{Statutes}

Developments in the area of 'nervous shock' have been primarily based in common law. Most states in Australia have statutorily addressed 'nervous shock' in one form or another. The original legislation in ACT, ${ }^{154} \mathrm{NSW},{ }^{155} \mathrm{NT},{ }^{156}$ South Australia, ${ }^{157}$ Tasmania, ${ }^{158}$ and Victoria ${ }^{159}$ provide that an action for personal injuries will not fail merely because the injury arose from nervous shock. It is interesting to note that one of the oldest, and also most comprehensive of these Acts, the Law Reform (Miscellaneous Provisions) Act, was passed in NSW as early as 1944 . The provisions relating to nervous shock were enacted following the decision in Chester $v$ Waverley Corporation ${ }^{160}$ that was subject to much community outrage. ${ }^{161}$

Following the Ipp Report, ${ }^{162}$ some of the States (namely ACT, ${ }^{163} \mathrm{NSW},{ }^{164} \mathrm{SA},{ }^{165}$ Tasmania, ${ }^{166}$ Victoria, ${ }^{167}$ and $\mathrm{WA}^{168}$ ) have recently introduced statutes that provide nervous shock extended coverage. Whilst Justice Malpass noted in Burke v New

\footnotetext{
${ }^{152}$ McLoughlin v O'Brian (1983) 1 AC 410, 419.

153 Joachim Dietrich, 'Nervous Shock: Tame v New South Wales and Annetts v Australian Stations Pty Ltd' (2003) 11(1) Torts Law Journal 1, 3.

${ }^{154}$ Law Reform (Miscellaneous Provisions) Act 1955 (ACT) s 23.

${ }^{155}$ Law Reform (Miscellaneous Provisions) Act 1944 (NSW) s 23.

${ }^{156}$ Law Reform (Miscellaneous Provisions) Act 1955 (NT) s 24.

${ }^{157}$ Civil Liability Act 1936 (SA) s 28.

${ }^{158}$ Wrongs Act 1954 (Tas) s 2 (see the definition of 'wrongful act').

${ }^{159}$ Wrongs Act 1958 (Vic) s 23.

160 (1939) 62 CLR 1. There the mother who suffered nervous shock when she saw the body of her seven year old son, after it had been dragged out from a deep trench in the road which had been dug and left unfenced by the local authority, was unable to recover. Perhaps what was more outrageous was the comments by Latham CJ - 'Death is not an infrequent event, and even violent and distressing deaths are not uncommon. It is, however, not a common experience of mankind that the spectacle, even of the sudden and distressing death of a child, produces any consequences more than a temporary nature in the case of bystanders or even close relatives who see the body after death has taken place.'

${ }^{161}$ Danuta Mendelson, 'The Defendant's Liability for Negligently Caused Nervous Shock in Australia Quo Vadis?' (1992) 18 Monash University Law Review 16; Mendelson, above n 5, 144.

${ }^{162}$ Law Reform Committee, above $\mathrm{n} 4$.

${ }^{163}$ Civil Law (Wrongs) Act 2002 (ACT) s 29-31.

${ }^{164}$ Civil Liability Act 2002 (NSW) Pt 3.

${ }^{165}$ Civil Liability Act 1936 (SA) s 33.

${ }^{166}$ Civil Liability Act 2003 (Tas) Pt 8 (s 29-35).

${ }^{167}$ Wrongs Act 1958 (Vic).

${ }^{168}$ Civil Liability Act 2002 (WA) s 5S
} 
South Wales and Others ${ }^{169}$ the statutes have changed the position at common law it is clear from the terminology adopted by the legislature that it has not moved too far from the position espoused in Annetts and Gifford. Additionally, although the principles espoused are similar in flavour to Recommendations 33-38 of the Ipp Report, there are some discrepancies. Before discussing the statutes in detail it is important to consider whether the legislation will exclude the operation of common law.

Following the enactment of the 1944 NSW statute, there was doubt as to whether someone other than a family member could recover in NSW by reason of an $e x$ pressio unius. ${ }^{170}$ The High Court, however, unanimously held in Gifford that the Act did not operate exclusively to the detriment of common law. In other words, if a claimant is unable to satisfy the statutory requirements, they are not precluded from seeking common law remedies for 'nervous shock'. This proposition, however, is unlikely to apply under the new statutory scheme in $\mathrm{NSW}^{171}$ and other States given that most have impliedly or expressly excluded common law redress. For instance, s 32 of the Civil Liability Act 2002 (Tas) and s 5S of the Civil Liability Act 2002 (WA) also appear to impliedly exclude common law recovery by making the statutory provisions the sole source of recovery for mental harm. The Victorian Wrongs Act 1958 espouses an intention that common law claims are also bound by the Act. ${ }^{172}$

Despite the exclusion of the common law in some States, the statutes do appear to provide greater assistance to claims for psychiatric illness, provided they come within the class of 'family members'. For instance, section 31 of the Civil Law (Wrongs) Act 2002 of ACT allows recovery for 'nervous shock' to an extended class of claimants. ${ }^{173}$ Under s 29 , the recoverable class includes grandparents, stepparents, someone acting in place of a parent, half-brothers and half-sisters, and grandchildren. Despite rejecting the definition of the class of claimants who may recover, the Ipp Report did suggest a similar class to the one mentioned above with the exclusion of grandparents and grandchildren. ${ }^{174}$ Grandparents and grandchildren have also not been included in the class by s 32 of the Tasmanian statute and s 30 of the NSW Act. Note however that WA and Victoria have not limited the class that may recover. The Civil Liability Act 1936 of SA, Civil Liability Act 2002 of WA, and the Civil Liability Act 2002 of Tasmania, are similar to the ACT legislation.

\footnotetext{
${ }^{169}$ [2004] NSWSC 725, [53]

${ }^{170}$ Mount Isa Mines v Pusey (1970) 125 CLR 383, 408 (Windeyer J).

${ }^{171}$ Section 28 of Civil Liability Act 2002.

${ }^{172}$ Section 68 and 73 of the Wrongs Act 1958 and the Explanatory Memoranda. It is also interesting to note that s 71 clearly states that the Victorian Act will not affect common law, except as provided by the Act.

${ }^{173}$ The class of claimants includes - a parent of the A (who is killed, injured or put in danger); spouse of A; a person (whether of the same sex or a different sex) who is living in a de facto marriage relationship with A; and another family member of A (if A was killed, injured or put in danger within the sight or hearing of the other family member).

${ }^{174}$ Law Reform Committee, above n 4, 9.27.
} 
The Civil Liability Act 2002 (NSW) has incorporated common law principles. Section 30 does not require any person who is defined as a close family member to have been at the scene of the incident although it is a factor to be considered under $\mathrm{s}$ 32. This is a change from the 1944 NSW statute which required presence at the scene. Under s 30(5), a close family member includes parents, grandparents, stepparents, someone acting in place of a parent, spouses, half-brothers and half-sisters, and grandchildren. Bystanders, however, are still precluded recovery unless they are at the scene.

In Burke, Justice Malpass held that if the claimant is not a close family member of the victim, he/she must demonstrate a number of matters. ${ }^{175}$ There has to be an identifiable victim, and the claimant has to witness the victim being killed, injured or put in peril, at the scene. In Burke the Plaintiff was not granted an extension of time to pursue his claim as the merits of the case did not warrant an extension, that is, he did not witness, at the scene, the victim (his friend) being killed, injured or put in peril.

Despite having extended the meaning of the class of claimants, under section 32 of the new Act the plaintiff must prove that '...the defendant ought to have foreseen that a person of normal fortitude might, in the circumstances of the case, suffer a recognised psychiatric illness if reasonable care were not taken.' The 'circumstances of the case', according to s 32(2), include - whether the mental harm was suffered as a result of sudden shock, whether the plaintiff was at the scene of the incident, the nature of the relationship between the plaintiff and the victim, and any pre-existing relationship between the plaintiff and the defendant. The statutes in WA, ${ }^{176}$ Tasmania, ${ }^{177}$ and Victoria ${ }^{178}$ have all required additional factors; similar to the ones mentioned in NSW, to be taken into account. In other words, the statutes have taken the common law factors into account. This may mean that only those at the scene of the accident or its immediate aftermath will be allowed recovery.

The new statutory schemes in NSW, Tasmania, Victorian and WA appear to have brought the legislative requirements for recovery in line with common law principles. Whilst what used to be 'control mechanisms' are now seen to be factors to be taken into account, it is likely that these considerations may act much the same way to prevent recovery, unless there is a close family relationship between the victim and the claimants. It is important to note that the High Court has allowed recovery, outside of the application of the three control mechanisms, only where there was some kind of pre-existing relationship between the plaintiff and the defendant. Even then it has been only allowed where the victim and the defendant were in an employee/employer relationship. The High Court, however, has indicated a liking for the case by case approach, and this may ameliorate the operation of the factors to be considered. Moreover, given that policy reasons for limiting recovery are no

\footnotetext{
175 [2004] NSWSC 725, [80].

${ }^{176}$ Civil Liability Amendment Act 2003 (WA) s 5S.

${ }^{177}$ Civil Liability Act 2003 (Tas) s 34.

${ }^{178}$ Wrongs and Other Acts (Law of Negligence) Act 2004 (Vic) ss 72 and 73.
} 
longer valid, all is not lost for 'television claimants' who suffer from genuine 'nervous shock'.

\section{COnCLusion}

The law has advanced some way towards allowing recovery for nervous shock by television viewers. Annetts and Gifford have provided a strong foundation for such claims. It is however important to note that the majority of judges in Annetts and Gifford require 'close ties of love and affection' and a pre-existing relationship between the secondary victims and the tortfeasor was a decisive factor. Absent a pre-existing relationship, 'direct perception' is likely to be a factor to be considered. Similarly, legislation enacted in the various States and Territories in Australia require direct perception to be proved unless there is a family relationship between the 'primary' victim and the claimant.

One must remember that although the common law and the legislature have demonstrated an ability to adapt to community standards and medical and technological advances, it is a slow and arduous process. At least now there is a willingness to break free of the so-called 'control mechanisms' of yesteryear. Now, the Supreme Court of New South Wales has been called upon in Klein to determine just how far the law has progressed. This responsibility should not be taken too lightly. 